\title{
EXCEPTIONALLY HIGH NUMBERS OF PURPLE FINCHES WINTERING IN SOUTHERN MANITOBA, 2016-2017
}

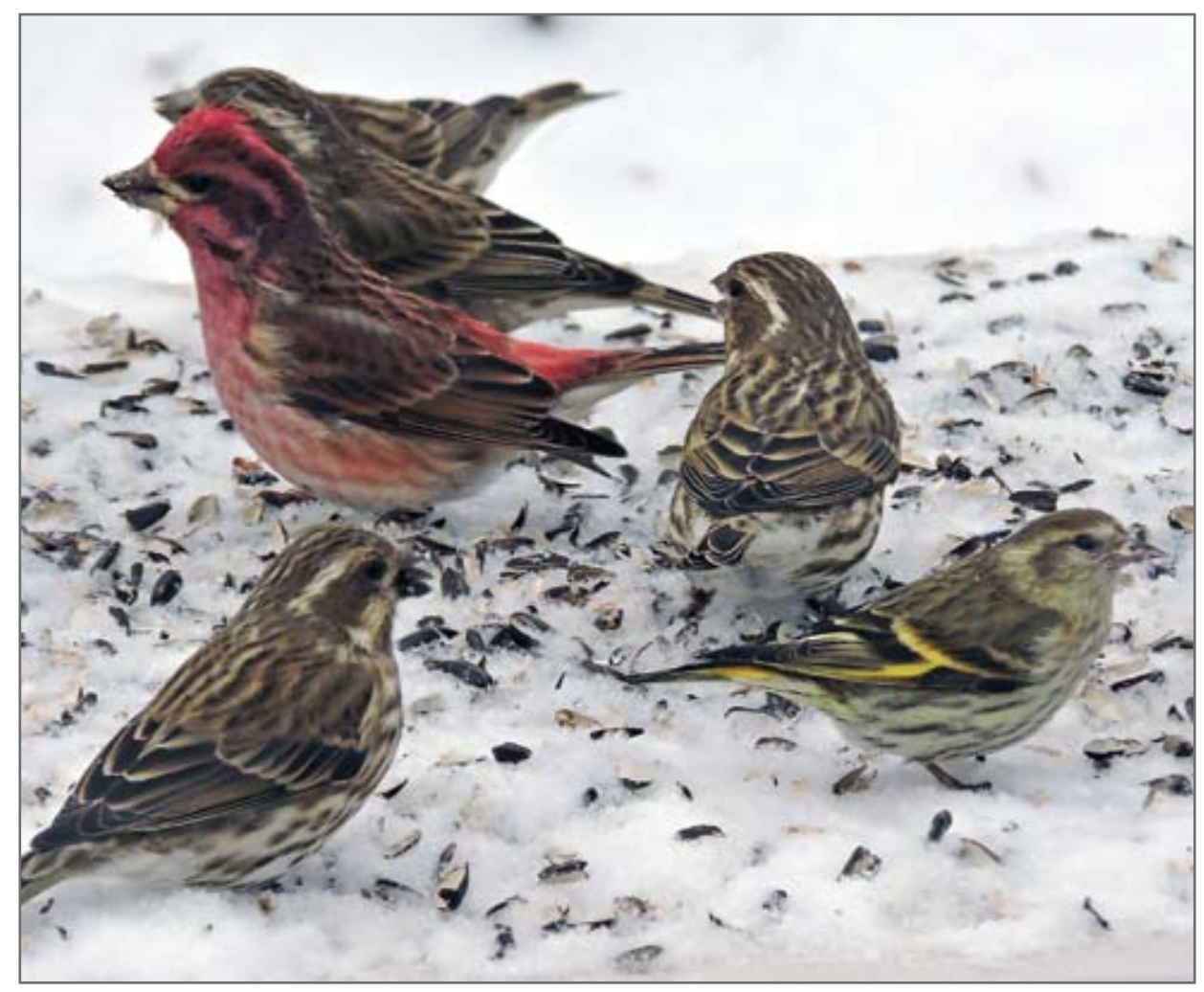

FIGURE 1. Purple Finches and a Pine Siskin (extreme right) at a Pinawa, Manitoba feeder on December 26, 2016. Bold dorsal streaking on the female-plumaged Purple Finches and the adult male's bright rump are typical of the eastern subspecies. Photo credit: Linda Huisman

\section{Peter Taylor}

P.O. Box 597, Pinawa, MB R0E 1 L0

taylorp@granite.mb.ca

This article documents exceptionally large numbers of Purple Finches (Haemorhous purpureus) that overwintered in southern Manitoba from November 2016 to March 2017. The Purple Finch breeds across Canada from British Columbia and southern Yukon to Newfoundland and southward to parts of the United States. ${ }^{1}$ Two subspecies are recognized: the eastern $H$. p. purpureus breeds as far west as the British Columbia interior, whereas $H$. p. californicus occurs along the Pacific coast. There is a large east-west component to migration of the eastern subspecies, which normally winters in the eastern United States and southern regions of eastern Canada., ${ }^{1,2}$ Southern Manitoba noteworthy. ${ }^{3}$ Although occurrence in winter remains sporadic, somewhat larger numbers have been recorded more recently, for example, a thenrecord total of 53 on the 2002 Pinawa - Lac du Bonnet CBC. ${ }^{5}$

Fall migration of Purple Finches in Manitoba is normally almost complete by the end of October. Thus, frequent sightings of small flocks in southern Manitoba in November 2016, both at feeders and at seed-bearing trees and shrubs, indicated that an unusual event was shaping up for the 20162017 winter. This was borne out by an extraordinary total of 382 Purple Finches recorded on the 2016 Pinawa - Lac du Bonnet CBC; while about $70 \%$ were found within the town of Pinawa, some were recorded by all but one of the seven parties of counters. Altogether in Manitoba, 729 Purple Finches were found on 15 of 21 counts; the previous record provincewide tally was 121 in 2008, with an average of 40 on two to ten counts between 2000 and 2015, inclusive. ${ }^{5}$

\section{Christmas Bird Counts and other counts}

The Pinawa - Lac du Bonnet area combined with north-south movements bounded by southern British Columbia, California, and Arizona. ${ }^{1}$

In Manitoba, Purple Finches breed primarily in the southern half of the boreal forest. ${ }^{3,4}$ They visit feeders, sometimes in large numbers during spring migration (late March to midMay), but wintering birds are typically singles or occasionally small flocks. While an increase in winter records was noted during the last quarter of the 20th century, Christmas Bird Count (CBC) totals of 30 at Cypress River - Spruce Woods on December 26, 1988 and 33 near Seven Sisters Falls (Pinawa - Lac du Bonnet CBC area) on December 28, 1996, as well as a flock of 14 at Victoria Beach on January 16, 1993, were considered especially lies at the southern fringe of the boreal forest in southeastern Manitoba. The next-highest 2016 CBC totals in the province were also in partly settled, forest-edge settings (130 at Glenboro Spruce Woods and 62 at Cypress River - Spruce Woods); these totals contrast with just two individuals in the urban/ suburban Winnipeg count, despite more intense coverage. Unusually high counts extended west and north to Brandon (46), Minnedosa (24), Riding Mountain National Park (30), Dauphin (12), and Hodgson (17). ${ }^{5}$ Purple Finches were also conspicuous at several feeders on Hecla Island (Lake Winnipeg) in January 2017. In Saskatchewan, altogether 43 Purple Finches were noted on seven of 95 counts, with 
most at Whitewood (20) and Nipawin (11); this is more than usual, but not a record. ${ }^{6}$ Similar patterns for Manitoba and Saskatchewan are evident for the Great Backyard Bird Count (February 17-20, 2017) and for eBird records as a whole for winter 2016-2017. ${ }^{7}$

I monitored the overwintering abundance of Purple Finches in Pinawa by counting them on 7-km walks on February 19 (during the Great Backyard Bird Count), March 15, and March 23, 2017, as well as observing them more casually throughout the winter. The three walks followed a convoluted route covering roughly half of the town-site, but taking in all known major feeder locations and concentration areas. Results, along with counts of other finches and selected CBC data, are compiled in Table 1.

The CBC data indicate that finch numbers were generally high on the 2016 Pinawa - Lac du Bonnet CBC, with the significant exception of the Evening Grosbeak, recently declared a species of Special Concern by the Committee on the Status of Endangered Wildlife in Canada. ${ }^{8}$ Only the Purple Finch was far above the previous range of fluctuating numbers. In general, "winter finches" are noted for their nomadic behaviour, linked to varying food supplies that result in highly variable numbers at given localities from year to year. ${ }^{9,10}$

The walking-count totals for Purple Finches in Pinawa, together with day-to-day observations, indicate that large numbers survived the winter, with many departing a little ahead of the normal spring passage (late March to mid-May). Fairly high but not exceptional numbers (up to several dozen) were noted at some Pinawa feeders during the latter period. High survival has also been inferred in other winters with smaller incursions, when localized concentrations were sustained throughout the season (personal observation).

Other information derived from the walking counts includes sustained high numbers of redpolls (especially at feeders) to mid-March, a midwinter influx of Pine Siskins (also mainly at feeders), and the normal March departure of Pine Grosbeaks, which are always in the vanguard of spring migration. ${ }^{11-13}$ The relatively low walking-count totals of both Evening and Pine grosbeaks are partly due to the late-morning/early-afternoon timing of the walks, after the typical, local morning peak of feeder activity for these two species (personal observation).

The number of colourful adult male Purple Finches was estimated at about $20 \%$; one feeder photograph showed just two adult males in a flock of 20 . Assuming a 1:1 sex ratio, this suggests a high proportion ( $60 \%$ ) of hatch-year birds, because young males moult from female-like Basic I (sub-adult) plumage into Definitive Basic (adult) plumage during the July-November period of their second year. ${ }^{1}$

The establishment of the House Finch ( $H$. mexicanus) as a breeding

\section{TABLE 1: Summary of counts of Purple Finches}

and other finches in and near Pinawa, Manitoba.

\begin{tabular}{|c|c|c|c|c|c|c|}
\hline SPECIES & $\begin{array}{c}\mathrm{CBC}^{\mathrm{a}} \\
30 \mathrm{DEC} \\
2016\end{array}$ & $\begin{array}{c}\text { CBC, } \\
\text { 10-YEAR } \\
\text { AVERAGE }\end{array}$ & $\begin{array}{l}\text { CBC RECORD } \\
\text { (YEAR) }\end{array}$ & $\begin{array}{l}\text { WALK, } \\
19 \text { FEB } \\
2017\end{array}$ & $\begin{array}{c}\text { WALK, } \\
15 \text { MAR } \\
2017\end{array}$ & $\begin{array}{c}\text { WALK, } \\
23 \text { MAR } \\
2017\end{array}$ \\
\hline Pine Grosbeak (Pinicola enucleator) & 422 & 297 & 742 (1996) & 47 & 4 & 0 \\
\hline Purple Finch (Haemorhous purpureus) & 382 & 6 & $382(2016)$ & 325 & 212 & 48 \\
\hline Red Crossbill (Loxia curvirostr) & 1 & 0 & $8(1979)$ & 0 & 0 & 0 \\
\hline White-winged Crossbill (L. leucoptera) & 47 & 37 & 151 (2009) & 0 & 0 & 0 \\
\hline Common Redpoll (Acanthis flammea) & 587 & 214 & $852(1987)$ & 449 & 493 & 92 \\
\hline Hoary Redpoll (A. hornemanni) & 12 & 5 & 45 (1984) & 1 & 0 & 0 \\
\hline Undetermined redpoll (Acanthis sp.) & 24 & 13 & -- & 0 & 0 & 0 \\
\hline Pine Siskin (Spinus pinus) & 22 & 2 & 259 (1987) & 97 & 75 & 33 \\
\hline American Goldfinch (S. tristis) & 0 & 0 & 55 (1979) & 0 & 0 & 0 \\
\hline Evening Grosbeak (Coccothraustes vespertinus) & 241 & 405 & $1663(1995)$ & 32 & 51 & 27 \\
\hline
\end{tabular}

${ }^{a}$ All CBC totals refer to the Pinawa - Lac du Bonnet count circle, which is centred at $50.1775^{\circ} \mathrm{N}, 95.9664^{\circ} \mathrm{W}$.

b Ten-year averages are for the period 2006-2015.

species in many prairie towns and cities, since the first individuals arrived during the 1980s, means that misidentification of House Finches as Purple Finches (or vice versa) by some observers is a potential confounding factor. ${ }^{4,14,15}$ Indeed, this is an ongoing issue for CBC compilers. Based on the author's field observations and correspondence, however, it was not a significant factor in the Pinawa - Lac du Bonnet area during the 2016-2017 winter. The House Finch remains a rare visitor to Pinawa and has not been detected there for some years. It is an uncommon breeder at Lac du Bonnet and some nearby communities, but the local population appears to be migratory. The species has been recorded just once on the Pinawa - Lac du Bonnet CBC: 24 birds on December 28,2002 . This coincided with the previous high count for Purple Finches, and the presence of both species within the count area at that time was verified by the author (as CBC compiler).

\section{Food supply, regional patterns, and interpretation}

Although large numbers of Purple Finches frequented well-stocked feeders (Fig. 1), they were also attracted to abundant crops of seeds on a number of wild and cultivated trees and shrubs, especially Black Ash (Fraxinus nigra), ornamental Amur Maple (Acer ginnala cultivars), and lilacs (Syringa sp. cultivars). My notes for February 19, 2017 state that while some Purple Finches were visiting feeders, where they mingled with redpolls and siskins, and others were still attracted to Amur Maple and lilac seeds, the majority were feeding in flocks of up to 20 on buds in Trembling Aspen (Populus tremuloides) and other deciduous trees. Purple Finches feed heavily on aspen catkins during spring migration, so it was interesting to see them feeding on these winter buds. ${ }^{3,11}$ On March 15, glaring light made it challenging to scan treetops, while a stiff breeze seemed to be discouraging Purple Finches from treetop feeding, a plausible explanation for the somewhat reduced count. By March 23, however, it was evident that most Purple Finches, as well as many other finches, had 
departed (see Table 1).

Remarkably, the 2016 Pinawa - Lac du Bonnet CBC total was the highest of 1,079 North American counts reporting Purple Finches during the 2016 CBC period, though only third in birds per party-hour of field effort (6.72). ${ }^{5}$ These birds were evidently part of a broader regional concentration, with the next three highest counts (excluding the Pacific Coast) being at Kenora, Ontario (292; 27.8 per party-hour; previous record 134 in 2014), Grand Marais, Minnesota (223; 4.90 per party-hour; previous record 35 in 2008), and Thunder Bay, Ontario (195; 2.09 per party-hour; all-time record 449 in 2002). The Atikokan, Ontario count was also noteworthy, with the secondhighest total per unit of effort $(97 ; 13.6$ per party-hour; previous record 83 in 2002). These five count localities lie within fairly narrow ranges of latitude $\left(47.8\right.$ to $\left.50.2^{\circ} \mathrm{N}\right)$ and longitude $(89.3$ to $96.0^{\circ} \mathrm{W}$ ), near the northwestern extremity of the published winter range. ${ }^{1} \mathrm{~A}$ brief review of Christmas counts in preceding years shows regional concentrations in New England (especially New Hampshire) in 2015 and Wisconsin in 2014, but no obvious regional peaks in 2011 to 2013. ${ }^{5}$

In eastern North America, Purple Finch migration is characterized by biennial incursions into the southern U.S. as far as the gulf states. ${ }^{1}$ While this alternation has been attributed to varying cone crops in the northern portion of this finch's wintering range, this explanation is problematic because conifer seeds do not appear to be a major component of the Purple Finch's varied winter diet of seeds and fruits. ${ }^{1}$ Koenig and Knops conducted a 30-year, continent-wide analysis of boreal finch numbers and coniferous seed crops. ${ }^{9}$ They concluded that Purple Finches erupted following years when breeding densities were high, for reasons apparently unrelated to the conifer seed crop; the variability in numbers was much less than for other boreal finches. Banding records indicate fidelity of Purple Finches to breeding sites, but not to wintering locales. ${ }^{2}$

The 2016-2017 winter incursion in southern Manitoba and neighbouring regions may be attributed to short- stop migration of birds originating somewhere in western Canada, prompted by an abundant and varied food supply. While the author lacks detailed data on food availability, there has been some decline in bird feeding in Pinawa since about 1990 (probably due to demographic changes in the town), and the 2016 Amur Maple seed crop appeared to be unusually heavy. The eastern and western subspecies are distinguishable by differences in vocalization and plumage; in particular, the western subspecies has more diffuse markings in female-type plumages. ${ }^{1}$ No such differences were noted during the winter incursion described here, suggesting that only the expected eastern subspecies was present.

The Pinawa - Lac du Bonnet area has long been a hot spot for winter finches, with Evening and Pine grosbeak CBC totals often in the top 10 for North America. Finches with more southerly winter ranges (Purple Finch, Pine Siskin, and American Goldfinch) are usually either scarce or absent, but CBC data show occasional spikes that are far above the low long-term averages (Table 1)..$^{5}$ It may therefore be many years before a comparable Purple Finch incursion occurs again in Manitoba. None was recorded in the 2017 Pinawa - Lac du Bonnet CBC, and the species was scarce or absent on 2017 counts throughout Manitoba and northwestern Ontario.

\section{Acknowledgements}

I thank J. Paul Goossen, Richard W. Knapton, and Rudolf F. Koes for helpful comments on a draft manuscript, an anonymous reviewer for further comments, and Linda Huisman for use of her photograph.

NOTE: All websites cited below were accessed on November 26, 2017

1. Wootton JT (1996) Purple Finch (Haemorhous purpureus), version 2.0. In: Rodewald PG (ed.) The Birds of North America. Cornell Lab of Ornithology, Ithaca, New York. https://doi.org/10.2173/bna.208.

2. Brewer D, Diamond AW, Woodsworth EJ, Collins BT, Dunn EH (2000) Canadian Atlas of Bird Banding, Volume 1: Doves, Cuckoos, and Hummingbirds through Passerines,
1921-1995. Special publication, Canadian Wildlife Service, Ottawa, Ontario.

3. Parsons RJ (2003) Purple Finch. In: Manitoba Avian Records Committee, The Birds of Manitoba, Manitoba Naturalists Society, Winnipeg, Manitoba, p. 387.

4. Artuso C, Couturier AR, De Smet KD Koes RF, Lepage D, McCracken J, Mooi R, Taylor P (Eds.) (2018). The Atlas of the Breeding Birds of Manitoba, 2010-2014. Bird Studies Canada. Winnipeg, Manitoba. www.birdatlas.mb.ca/.

5. Audubon Christmas Bird Count. www.audubon.org/conservation/science/ christmas-bird-count.

6. Smith AR (2017) 75th Annual Saskatchewan Christmas Bird Count - 2016. Blue Jay 75(3):32-44.

7. eBird Canada, www.ebird.org/content/ canada/.

8. COSEWIC (2016). COSEWIC assessment and status report on the Evening Grosbeak Coccothraustes vespertinus in Canada. Prepared by C. Savignac. Committee on the Status of Endangered Wildlife in Canada. Ottawa, Ontario www.registrelep-sararegistry.gc.ca/default. asp?lang=en \&n=24F7211B-1

9. Koenig WD, Knops JMH (2001) Seed-crop size and eruptions of North American boreal seed-eating birds. Journal of Animal Ecology 70:609-620.

10. Pittaway R (2016) Ron Pittaway's winter finch forecast 2016-2017. www.ebird.org/ content/canada/news/ron-pittaways-winterfinch-forecast-2016-2017/.

11. Taylor P (1983) Wings along the Winnipeg: the birds of the Pinawa-Lac du Bonnet region, Manitoba. Eco Series No. 2, Manitoba Naturalists Society, Winnipeg, Manitoba (reprinted with minor revisions, 1985).

12. Taylor P (1996) Winter songs of the Pine Grosbeak. Blue Jay 54:82-84.

13. Taylor P (2003) Pine Grosbeak. In: Manitoba Avian Records Committee, The Birds of Manitoba, Manitoba Naturalists Society, Winnipeg, Manitoba, pp. 386-387.

14. Bancroft J, Parsons RJ (1991) Range expansion of the House Finch into the Prairie Provinces. Blue Jay 49:128-136.

15. Parsons RJ (2003) House Finch. In: Manitoba Avian Records Committee, The Birds of Manitoba, Manitoba Naturalists Society, Winnipeg, Manitoba, pp. 388-389.

\section{?}

SPRING 2018 VOLUME 76.1 BLUE JAY 7 